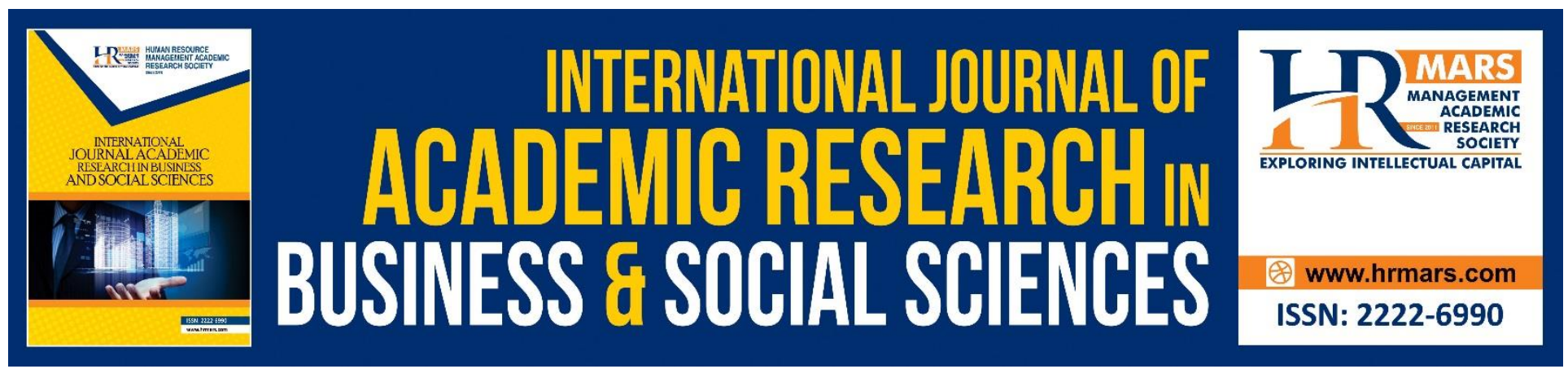

\title{
A Systematic Literature Review on the Problem-Posing Strategies for Biology Problem-Posing Multimedia Module Design
}

Nor Tutiaini Ab. Wahid, Othman Talib, Tajularipin Sulaiman, Mohd Hazwan Mohd Puad

To Link this Article: http://dx.doi.org/10.6007/JJARBSS/v8-i12/5150

DOI: $10.6007 /$ IJARBSS/v8-i12/5150

Received: 30 Oct 2018, Revised: 03 Dec 2018, Accepted: 15 Dec 2018

Published Online: 26 Dec 2018

In-Text Citation: (Wahid, Talib, Sulaiman, \& Puad, 2018)

To Cite this Article: Wahid, N. T. A., Talib, O., Sulaiman, T., \& Puad, M. H. M. (2018). A Systematic Literature Review on the Problem-Posing Strategies for Biology Problem-Posing Multimedia Module Design. International Journal of Academic Research in Business and Social Sciences, 8(12), 1020-1032.

Copyright: (C) 2018 The Author(s)

Published by Human Resource Management Academic Research Society (www.hrmars.com)

This article is published under the Creative Commons Attribution (CC BY 4.0) license. Anyone may reproduce, distribute, translate and create derivative works of this article (for both commercial and non-commercial purposes), subject to full attribution to the original publication and authors. The full terms of this license may be seen at: http://creativecommons.org/licences/by/4.0/legalcode

Vol. 8, No. 12, 2018, Pg. 1020 - 1032

Full Terms \& Conditions of access and use can be found at http://hrmars.com/index.php/pages/detail/publication-ethics 


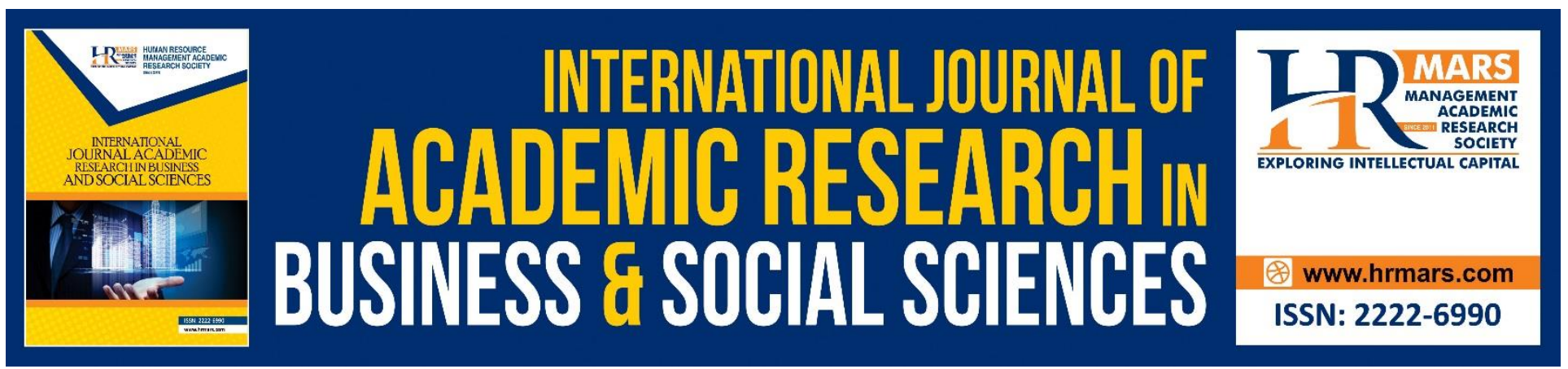

\title{
A Systematic Literature Review on the Problem- Posing Strategies for Biology Problem-Posing Multimedia Module Design
}

\author{
Nor Tutiaini Ab. Wahid*, Othman Talib, Tajularipin Sulaiman, Mohd \\ Hazwan Mohd Puad
}

Faculty of Educational Studies, Universiti Putra Malaysia, 43400 UPM Serdang, Selangor Darul Ehsan, Malaysia

\begin{abstract}
Numerous research has documented the debate fuelled by scholars pertaining to problem-posing strategy in Mathematics. It has been argued that this strategy is capable of instilling student's problem-solving skills. However, despite its popularity in Mathematics, the application on other subjects such as Biology particularly, via a media technology is still sparse. This study aims at identifying suitable strategies to be incorporated into a proposed multimedia module namely, Problem-Posing Multimedia Module (PPMM). To achieve the objective, a systematic literature review has been executed. This paper elaborates on the rigorous systematic literature review process done on the 289 selected journal articles and papers on problem-posing strategies topic. The analysis reveals that, while different field applies different strategies of problem-posing, most of them share similar themes in implementing problem-posing instructional strategies. These are communication, collaboration, creativity and critical thinking, which are part of the elements advocated in the $21^{\text {st }}$ century learning. These findings act as a heuristic device to propose a development of a problemposing multimedia activity module.

Keywords: Problem-posing, Multimedia Module, Biology Education, Systematic Literature Review, Classroom Practices

\section{Introduction}

Problem-posing is one of the instructional strategies in a classroom that requires critical thinking to succeed. This theory originates from Paolo Freire (1970), known as 'pedagogy of the oppressed'. In this theory, the oppressed recognizes the cause of their oppression from which they create a new situation. This theory of critical thinking is rooted from constructivist theory (Cankoy, 2014) advocating that knowledge is constructed by an individual using his/her own experiences. The philosophy that underpins problem-posing lies in that learning has to be 'between' the teacher and
\end{abstract}


the students not 'from' the teacher to the students (Kontorovich, Koichu, Leikin, \& Berman, 2012). Problem-posing is considered as a special case of problem solving because the process is moving from a current state to a new generation of state (Leung, 2013). Students develop a concept by assimilating their intuitive or personal experiences about the natural world with a scientific idea presented in the classroom. In many cases, the process of assimilating will lead to misconceptions. Problem-posing is a good tool for teachers to evaluate cognitive processes of the students and find out the misconception occurs among their students (da Ponte \& Henriques, 2013). Through problemposing activity, teachers are able to identify the misconceptions among students in the way they pose questions and provided answers for their own questions. From there on, teachers can put a dialogue with the students to clear any misconceptions. Striking of new ideas lead to conceptual change that restructures students existing concepts. Problem-posing is profoundly accepted to increase students' motivation and help to improve students' achievement (Beal \& Cohen, 2012).

To date, problem-posing is commonly used in mathematics. Acknowledging its benefits, this paper attempts to discuss how problem-posing can be applied in Biology. Biology is traditionally known as a subject with loads of facts to be memorized (Sousa, 2016). However, the critical thinking and problem solving skills needed underneath the memorisation process are unnoticeable for many people. Taking a simple example, to be able to explain why plants become wilt during a hot day, students need to understand the movements of substances through plasma membrane that occurred inside the plant's cells. These biology processes are usually hardly understood since these cannot be easily observed via eyes.

In order to explain such cell processes, much efforts has been done to transform them into animation and multimedia presentation (Beal \& Cohen, 2012; Sousa, 2016). In this study, multimedia elements will be embedded together with problem-posing strategy to develop a module to enhance students learning experiences. The module called as Problem-posing Multimedia Module (PPMM). Multimedia presentation is one of the powerful tools to create a meaningful learning among the students (Mayer, 2010). Scholars argue that the use of multimedia presentation could help students to construct better visual mental models representing the abstract, dynamic and complex processes in Biology compared to static illustration (Çimer, 2012; Sousa, 2016).

To make sure that PPMM would be helpful for students in generating new ideas and addressing the misconceptions, activities, and strategies in PPMM must be carefully selected and designed for the module so that they can really benefit the students and teachers during the teaching and learning processes. To do this, previous studies on this topic were scrutinised. Hence, a systematic literature review method was executed to identify the strategies and activities, suitable for PPMM.

\section{Systematic Literature Review Method}

The aim of this study is to identify the suitable problem-posing strategies for Biology classroom. The identified strategies will then be designed and developed to compose a multimedia module called Problem-posing Multimedia Module (PPMM). The research questions that guide this study are as follows: 
i. What are the suitable problem-posing strategies to be incorporated into the PPMM for Biology classroom?

ii. What are the relevant problem-posing activities to be included in PPMM for Biology classroom?

The systematic literature review (SLR) method was used to analyse papers pertaining to suitable strategies and activities of problem-posing in a classroom. There are four stages of SLR method which are identification, screening, eligibility and inclusion (Nunes, Luz, Lemos, \& Nunes, 2016). In the identification phase (Figure 1), four strings were used to search for relevant articles. These are, problem-posing; problem-posing AND activities; problem-posing AND strategies; problem-posing AND instructional AND strategies. The effort successfully captured a total of 289 papers. In this stage, open access journal was used and the database ranged from Emerald, Science Direct, Springer, Sage, Taylor and Francis, and Web of Science. The word AND was used in the search string to add a wide range of findings and expand the search into a specific study of problem-posing (Rosli, Capraro, \& Capraro, 2014).

In the screening phase, redundant papers were eliminated leaving 285 relevant papers. Then, the relevant papers were further scrutinised to narrow down to problem-posing topic leading to exclusion of another 197 papers. With the remaining 88 papers, the process was continued by filtering the titles and abstracts. This step revealed 32 papers with the same theme of problem-posing strategies. Since the final resort of this SLR method was to include the most relevant papers that contain classroom problem-posing strategies and activities regardless of subjects or fields, a thorough step was further executed on the remaining papers. As a result, 14 papers were found to represent the classroom problem-posing strategies and activities. These papers - with some kinds of evidence on students' performance achievements documented-were closely examined in the further steps. It was found that these papers were somehow interconnected by the strategies used, activities created and representation of framework. The succeeding sections of this paper summarize the problem-posing strategies used in each paper. 
INTERNATIONAL JOURNAL OF ACADEMIC RESEARCH IN BUSINESS AND SOCIAL SCIENCES

Vol. 8, No. 12, Dec, 2018, E-ISSN: 2222-6990 C 2018 HRMARS

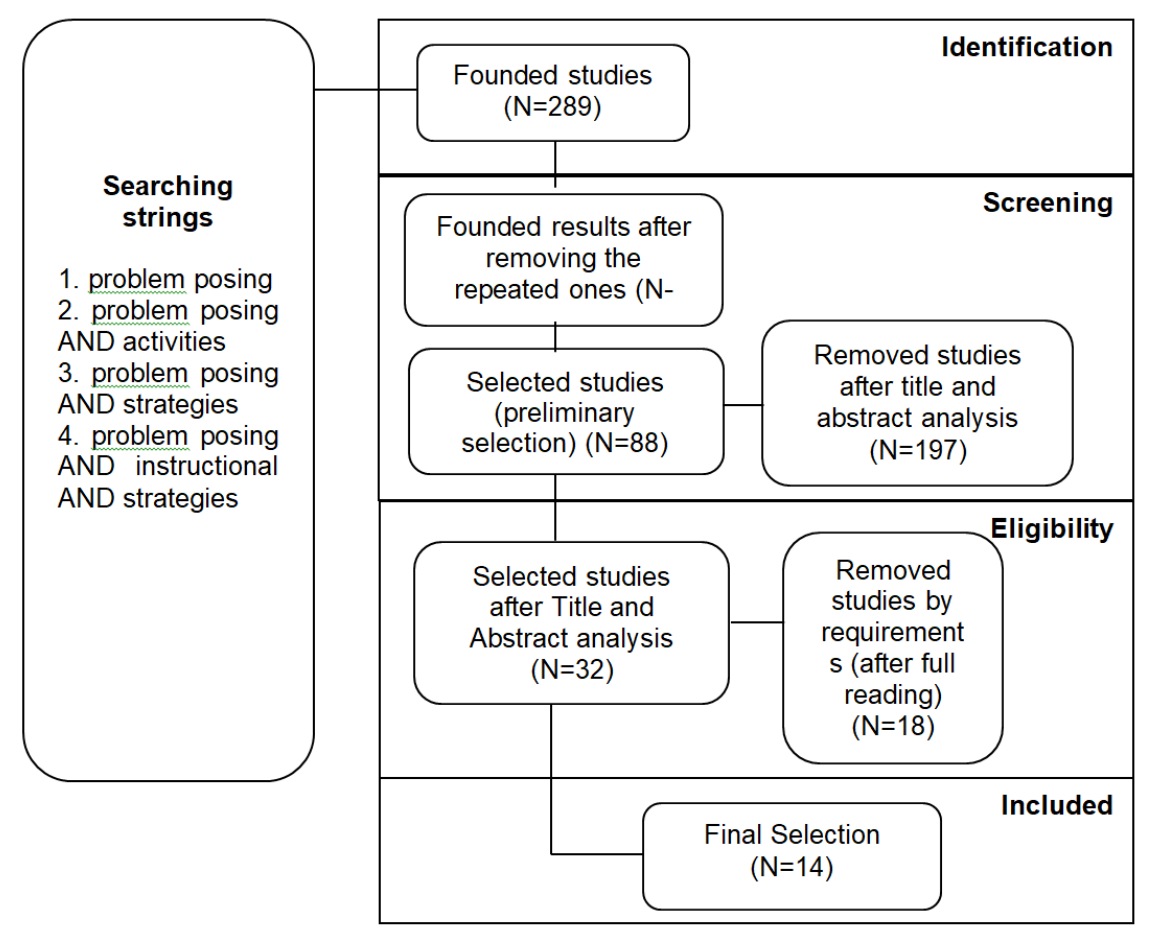

Fig. 1. Distribution of studies included and excluded from systematic review

\section{Analysis}

The first stage of this analysis is to identify the problem-posing strategies and activities that have been used in classrooms. As there are many instructional strategies available, the paper selection must be carefully and closely adhered to the problem-posing instructional strategies. Papers that explain strategies but do not employ problem-posing terms were considered ineligible for this analysis. As such, these papers were eliminated.

\section{Problem-posing Strategies and Activities Analysis}

In this section, analysis of the content of 14 papers is elaborated. Strategies and activities were extracted and listed in Table 1 before a content-analysis was commenced.

Table 1: Analysis of Problem-Posing Strategies and Activities by Paper

\begin{tabular}{l|l|l|l|l}
\hline Author (s) & $\begin{array}{l}\text { Study } \\
\text { domain }\end{array}$ & Strategies & Activities & Remarks \\
\hline $\begin{array}{l}\text { (da Ponte \& } \\
\text { Henriques, } \\
\text { 2013) }\end{array}$ & $\begin{array}{l}\text { Educational } \\
\text { studies in } \\
\text { Mathematics }\end{array}$ & $\begin{array}{l}\text { Investigation } \\
\text { task }\end{array}$ & $\begin{array}{l}\text { 1. presenting tasks } \\
\text { 2. exploring } \\
\text { 3. presenting } \\
\text { discussing students' } \\
\text { conclusions }\end{array}$ & $\begin{array}{l}\text { Strategy is } \\
\text { not suitable } \\
\text { for PPMM. }\end{array}$ \\
& & & $\begin{array}{l}\text { Presentation } \\
\text { activity is } \\
\text { suitable for } \\
\text { PPMM }\end{array}$ \\
\hline
\end{tabular}


INTERNATIONAL JOURNAL OF ACADEMIC RESEARCH IN BUSINESS AND SOCIAL SCIENCES Vol. 8, No. 12, Dec, 2018, E-ISSN: 2222-6990 @ 2018 HRMARS

\begin{tabular}{|c|c|c|c|c|}
\hline $\begin{array}{l}\text { (Kontorovich } \\
\text { et al., 2012) }\end{array}$ & $\begin{array}{l}\text { Mathematic } \\
\text { education }\end{array}$ & Workshop & $\begin{array}{l}\text { 1. Form a small group } \\
\text { 2. Pose a problem in a } \\
\text { group } \\
\text { 3. Answer their own } \\
\text { questions } \\
\text { 4. Pose as many questions } \\
\text { to be answered by other } \\
\text { group }\end{array}$ & $\begin{array}{l}\text { Strategy and } \\
\text { activities are } \\
\text { suitable for } \\
\text { PPMM }\end{array}$ \\
\hline $\begin{array}{l}\text { (Beal \& } \\
\text { Cohen, 2012) }\end{array}$ & Education & $\begin{array}{l}\text { Online } \\
\text { application } \\
\text { Situation }\end{array}$ & $\begin{array}{l}\text { 1. Students register the } \\
\text { online application } \\
\text { through their teacher } \\
\text { 2. Answer the problem } \\
\text { pose earlier by teacher } \\
\text { 3. Pose a new problem } \\
\text { based on given question }\end{array}$ & $\begin{array}{l}\text { Strategy is } \\
\text { not suitable } \\
\text { for PPMM. } \\
\text { Activity pose } \\
\text { a problem is } \\
\text { suitable for } \\
\text { PPMM. }\end{array}$ \\
\hline Author (s) & $\begin{array}{l}\text { Study } \\
\text { domain }\end{array}$ & Strategies & Activities & Remarks \\
\hline $\begin{array}{l}\text { (Singer \& } \\
\text { Voica, 2013) }\end{array}$ & $\begin{array}{l}\text { Educational } \\
\text { studies in } \\
\text { Mathematics }\end{array}$ & $\begin{array}{l}\text { Camping } \\
\text { activities }\end{array}$ & $\begin{array}{l}\text { 1. Students were ask to } \\
\text { create two problems } \\
\text { (one is easy another one } \\
\text { is hard) } \\
\text { 2. In group they will discuss } \\
\text { the solution } \\
\text { 3. The students that create } \\
\text { the good questions and } \\
\text { find the solution were } \\
\text { then interviewed for } \\
\text { further discussion }\end{array}$ & $\begin{array}{l}\text { Strategy is } \\
\text { not suitable } \\
\text { for PPMM. } \\
\text { Group } \\
\text { discussion } \\
\text { and create a } \\
\text { problem } \\
\text { activities are } \\
\text { suitable for } \\
\text { PPMM. }\end{array}$ \\
\hline (Kapur, 2015) & $\begin{array}{l}\text { Learning \& } \\
\text { instruction } \\
\text { (Mathematic) }\end{array}$ & Lecturing & $\begin{array}{l}\text { 1. Lecturer will give lecture } \\
\text { regarding the topic } \\
\text { 2. Students then given a } \\
\text { blank A4 paper to write } \\
\text { down any questions } \\
\text { 3. Students will find a } \\
\text { solution to their own } \\
\text { questions based on } \\
\text { lecture given and prior } \\
\text { knowledge }\end{array}$ & $\begin{array}{l}\text { Strategy and } \\
\text { activities are } \\
\text { suitable for } \\
\text { PPMM. }\end{array}$ \\
\hline
\end{tabular}


INTERNATIONAL JOURNAL OF ACADEMIC RESEARCH IN BUSINESS AND SOCIAL SCIENCES Vol. 8, No. 12, Dec, 2018, E-ISSN: 2222-6990 @ 2018 HRMARS

\begin{tabular}{|c|c|c|c|c|}
\hline $\begin{array}{l}\text { (Nardone \& } \\
\text { Lee, 2010) }\end{array}$ & $\begin{array}{l}\text { Critical } \\
\text { thinking }\end{array}$ & $\begin{array}{ll}\text { Daily } & \text { life } \\
\text { activities } & \end{array}$ & $\begin{array}{l}\text { 1. Self-reflection } \\
\text { 2. Modelling } \\
\text { 3. Metaphor } \\
\text { 4. Grappling } \\
\text { 5. Synthesis }\end{array}$ & $\begin{array}{l}\text { Strategy and } \\
\text { activities are } \\
\text { not suitable } \\
\text { for PPMM. }\end{array}$ \\
\hline $\begin{array}{l}\text { (Cankoy, } \\
\text { 2014) }\end{array}$ & $\begin{array}{l}\text { Mathematics } \\
\text { Education } \\
\text { Cognitive } \\
\text { engagement }\end{array}$ & $\begin{array}{l}\text { Group } \\
\text { discussion }\end{array}$ & $\begin{array}{l}\text { 1. Teacher will writes a } \\
\text { potential problem to be } \\
\text { solve on the whiteboard } \\
\text { with a missing data } \\
\text { 2. Teacher choose a } \\
\text { student and ask him to } \\
\text { add the potential missing } \\
\text { data on the whiteboard } \\
\text { 3. Teacher will initiate a } \\
\text { class discussion to find a } \\
\text { solution }\end{array}$ & $\begin{array}{l}\text { Strategy } \\
\text { group } \\
\text { discussion is } \\
\text { suitable for } \\
\text { PPMM. } \\
\text { Activities are } \\
\text { not suitable } \\
\text { for PPMM }\end{array}$ \\
\hline Author (s) & $\begin{array}{l}\text { Study } \\
\text { domain }\end{array}$ & Strategies & Activities & Remarks \\
\hline $\begin{array}{l}\text { (Mishra \& } \\
\text { lyer, 2015) }\end{array}$ & $\begin{array}{l}\text { Computer } \\
\text { Science } \\
\text { application }\end{array}$ & $\begin{array}{l}\text { Group } \\
\text { activities }\end{array}$ & $\begin{array}{l}\text { 1. Apply } \\
\text { 2. Organize } \\
\text { 3. Probe } \\
\text { 4. Compare } \\
\text { 5. Connect } \\
\text { 6. Vary } \\
\text { 7. Implement }\end{array}$ & $\begin{array}{l}\text { Strategy and } \\
\text { activities are } \\
\text { suitable and can } \\
\text { be implemented } \\
\text { in one of the } \\
\text { session in PPMM. }\end{array}$ \\
\hline $\begin{array}{l}\text { (Chang, Wu, } \\
\text { Weng, \& } \\
\text { Sung, 2012) }\end{array}$ & $\begin{array}{l}\text { Computers } \\
\text { education }\end{array}$ & $\begin{array}{l}\text { Game } \\
\text { scenarios }\end{array}$ & $\begin{array}{l}\text { 1. Posing problem } \\
\text { 2. Planning } \\
\text { 3. Solving problem } \\
\text { 4. Looking back }\end{array}$ & $\begin{array}{l}\text { Strategy is } \\
\text { not suitable } \\
\text { for PPMM. } \\
\text { Activities are } \\
\text { suitable for } \\
\text { PPMM. }\end{array}$ \\
\hline $\begin{array}{l}\text { (Sung, } \\
\text { Hwang, \& } \\
\text { Chang, 2013) }\end{array}$ & $\begin{array}{l}\text { Computers } \\
\text { education }\end{array}$ & $\begin{array}{l}\text { Collaborative } \\
\text { mobile } \\
\text { learning }\end{array}$ & $\begin{array}{l}\text { 1. Students log in by } \\
\text { scanning the QR code } \\
\text { 2. Students were asked to } \\
\text { answer questions } \\
\text { 3. Students create other } \\
\text { questions if they still } \\
\text { don't understand the } \\
\text { task target }\end{array}$ & $\begin{array}{l}\text { Strategy is } \\
\text { not suitable } \\
\text { for PPMM. } \\
\text { Activities } \\
\text { create } \\
\text { questions is } \\
\text { suitable for } \\
\text { PPMM. }\end{array}$ \\
\hline
\end{tabular}




\begin{tabular}{|c|c|c|c|c|}
\hline & & & $\begin{array}{l}\text { 4. The learning complete } \\
\text { once the students have } \\
\text { no further questions } \\
\text { regarding the task }\end{array}$ & \\
\hline $\begin{array}{l}\text { (N. Hasanah, } \\
\text { Hayashi, \& } \\
\text { Hirashima, } \\
\text { 2017) }\end{array}$ & $\begin{array}{l}\text { Mathematics } \\
\text { education }\end{array}$ & $\begin{array}{l}\text { Posing } \\
\text { arithmetic } \\
\text { word problems } \\
\text { using tablet } \\
\text { software }\end{array}$ & $\begin{array}{l}\text { 1. Students were given } \\
\text { extraneous problem } \\
\text { through tablet software } \\
\text { 2. Teaching activity } \\
\text { conducted by teacher } \\
\text { 3. Students pose a problem } \\
\text { using simple words given }\end{array}$ & $\begin{array}{l}\text { Strategy is } \\
\text { not suitable } \\
\text { for PPMM. } \\
\text { Activities } \\
\text { pose a } \\
\text { problem is } \\
\text { suitable for } \\
\text { PPMM. }\end{array}$ \\
\hline $\begin{array}{l}\text { (Nerida } \quad F, \\
2015)\end{array}$ & $\begin{array}{l}\text { Mathematics } \\
\text { education }\end{array}$ & $\begin{array}{l}\text { Mathematical } \\
\text { modelling class }\end{array}$ & $\begin{array}{l}\text { 1. Students drafted } \\
\text { mathematical modelling } \\
\text { problems } \\
\text { 2. Students shared their } \\
\text { problem with their peers } \\
\text { 3. Presenting their } \\
\text { problems to the class }\end{array}$ & $\begin{array}{l}\text { Strategy is } \\
\text { not suitable } \\
\text { for PPMM. } \\
\text { Activities are } \\
\text { suitable for } \\
\text { PPMM. }\end{array}$ \\
\hline
\end{tabular}

\section{Content-Analysis on Problem-posing Strategies and Activities}

As illustrated in Table 1, each paper represents a small difference in strategies and activities. Some of the strategies may not be suitable to be included in the PPMM module due to time constraint (Nardone \& Lee, 2010; Chang et al., 2012; da Ponte \& Henriques, 2013; Nerida F, 2015). Exemplifying these are strategies like collaborative mobile learning (Sung et al., 2013), arithmetic word problems using tablet software (N. Hasanah et al., 2017) and online application situation (Beal \& Cohen, 2012). In addition, these strategies use devices, gadgets and require a good internet connection which may not be available in the classroom setting. With a limited infrastructure that supports the use of online mobile educational technology, the PPMM module would only focus on strategies like group discussion, imitation of questions, and lecturing. Having the similar exposure time and adapting the average learning ecosystem facility, these strategies deem to be the most appealing for PPMM (Kojima, Miwa, \& Matsui, 2013; Leung, 2013; Cankoy, 2014; Kapur, 2015).

However, it is noteworthy that some attributes with similar themes contribute to problem-posing emerged from the analysis. Throughout the content analysis via Atlas.ti, four main themes emerged: critical thinking, communication, collaboration, and creativity. Even though most of the papers fall into Mathematical education domains, the strategies discussed can be modified to fit into Biology classroom based on these similar themes. Activities such as creating problems and questions, find solution to their own questions and solving problem require students to think critically. Students have to communicate and collaborate with their peers in order to find the solutions to their own questions. In order to write down their questions and presenting their answers, students need to restructure 
INTERNATIONAL JOURNAL OF ACADEMIC RESEARCH IN BUSINESS AND SOCIAL SCIENCES Vol. 8, No. 12, Dec, 2018, E-ISSN: $2222-6990$ c 2018 HRMARS

the information in creative ways to be understood by others. The process of identifying and determining the themes from the strategies and activities are summarized in the network in Figure 2, Figure 3, Figure 4 and Figure 5.

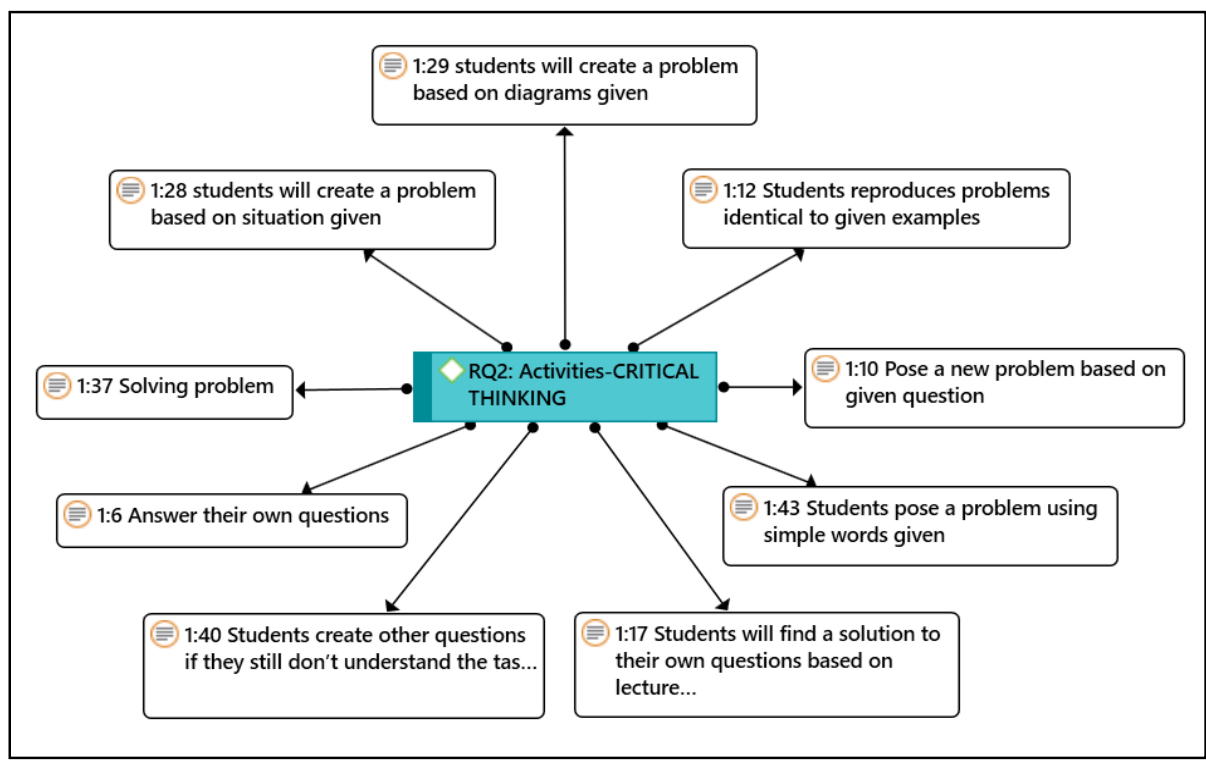

Fig. 2. Activities in papers that shared critical thinking theme

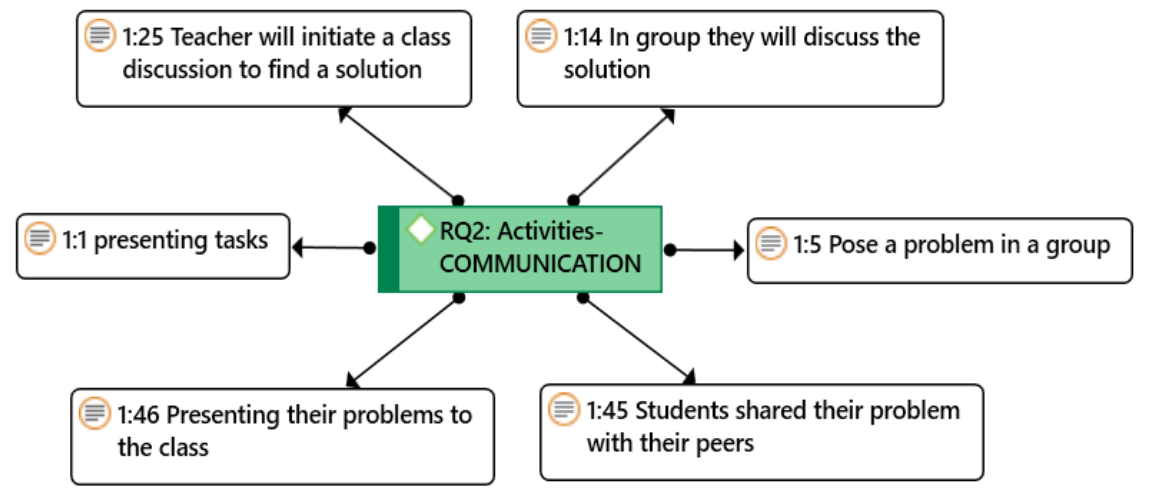

Fig. 3. Activities evidenced in papers with shared communication theme

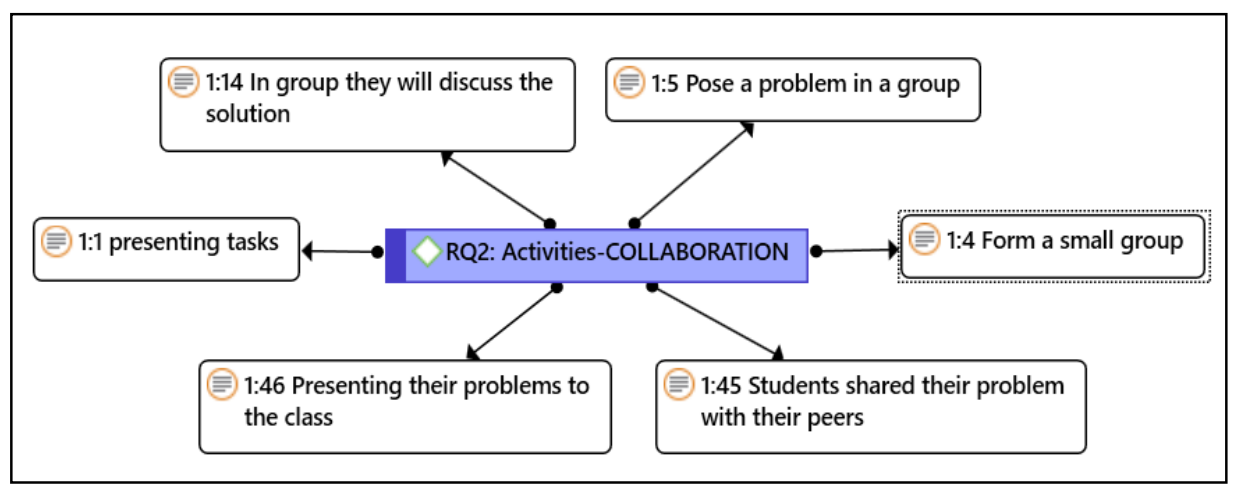


INTERNATIONAL JOURNAL OF ACADEMIC RESEARCH IN BUSINESS AND SOCIAL SCIENCES Vol. 8, No. 12, Dec, 2018, E-ISSN: 2222-6990 C 2018 HRMARS

Fig. 4. Activities evidenced in papers with shared collaboration theme

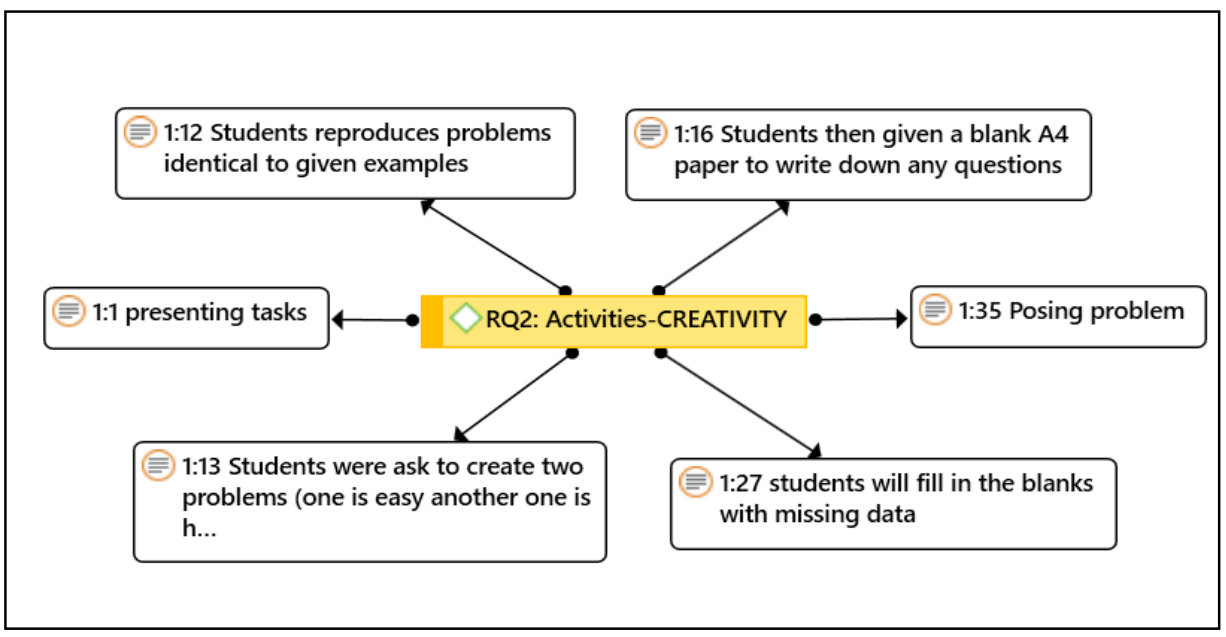

Fig. 5. Activities evidenced in papers with shared creativity theme

Reflecting on the approaches, it is found that most of the papers share the same theme. Students will retrieve information from the lecture, then they will be asked to create a problem either from a situation or imitation of questions (Christou, Mousoulides, Pittalis, Pitta-Pantazi, \& Sriraman, 2005; Nardone \& Lee, 2010; Beal \& Cohen, 2012; Chang et al., 2012; Leung, 2013; Singer \& Voica, 2013; Sung et al., 2013; Kapur, 2015; Nerida F, 2015; Mishra \& lyer, 2015; N. Hasanah et al., 2017). Giving a situation with a missing data also is a good activity since it improves students thinking and allows them to apply the situation in daily life (Christou et al., 2005). This activity allows students to figure out what information is still missing or cannot be grasped during the lecture. By detecting their own problems followed by creating their own questions, it is argued that they may find a better solution to the problem (Christou et al., 2005; Nardone \& Lee, 2010; Chang et al., 2012). This learning strategy enhances the thinking skills and allows students to be more creative too (Beal \& Cohen, 2012; Cankoy, 2014; Mishra \& lyer, 2015). After posing the problems, activities shift to discussion tasks. Students share their problems with their peers (Nardone \& Lee, 2010; Chang et al., 2012; da Ponte \& Henriques, 2013; Singer \& Voica, 2013; Cankoy, 2014; Nerida F, 2015; N. Hasanah et al., 2017). After discussion have been performed and solutions have been determined, students present their problems and answers to the class (Nardone \& Lee, 2010; Chang et al., 2012; da Ponte \& Henriques, 2013; Cankoy, 2014; Nerida F, 2015; N. Hasanah et al., 2017). In general, based on the results from the papers selected, it is promising to see that having students engaged in problem-posing activities lead to wider benefits on students' achievement, problem solving skills, levels of problems posed, and attitudes toward learning activities (Rosli et al., 2014). Thus, problem-posing instructional approach is found to be an encouraging conduct in enhancing thinking skills among students if correct strategies and suitable activities are implemented.

\section{Strategies and Activities in PPMM}


INTERNATIONAL JOURNAL OF ACADEMIC RESEARCH IN BUSINESS AND SOCIAL SCIENCES Vol. 8, No. 12, Dec, 2018, E-ISSN: 2222-6990 @ 2018 HRMARS

Based on the analysis done in the previous section, there are three main strategies that have been identified and found suitable for PPMM module. These are; 1) Lecturing 2) Imitation of questions 3) Group discussion. Each strategy is mentioned in papers listed in Table 1. For the first strategy, a teacher will teach students on the chosen topic. A multimedia module will be used during class to enhance the transfer of information to the students based on cognitive multimedia learning theory (Mayer, 2010). In the multimedia module, a few problems will be posed to arouse curiosity in the students. In the second strategy, students will be provided with examples of the question for them to imitate and reconstruct other questions regarding the concepts that they do not understand. While in the third strategy, students will be asked to form a small group to engage in group discussion.

Findings from the previous section entail that there are four relevant activities that seem appealing for the development of the PPMM which are; 1) Posing a problem 2) Giving situation with missing data 3) Finding answers to their own questions 4) Presenting their completed work. The first step is a phase where students pose questions after listening to teacher's lesson. The questions will be written down in a space provided in the module. This stage requires the students to be creative and critical. Then, they will form a small group, and start discussing the answers with their peers in a given time. Here communication and collaborative skills are emphasized. Later, in the final stage, they will share and present their problems and solutions to the class. In certain activities, students also will be given a situation with a missing data regarding the topic and they will be asked to find a solution from the situation given. Throughout the activities, teacher acts as a facilitator and needs to interfere if any of the answers is not appropriately presented. Figure 6 depicts the summary of the strategies and steps involved.

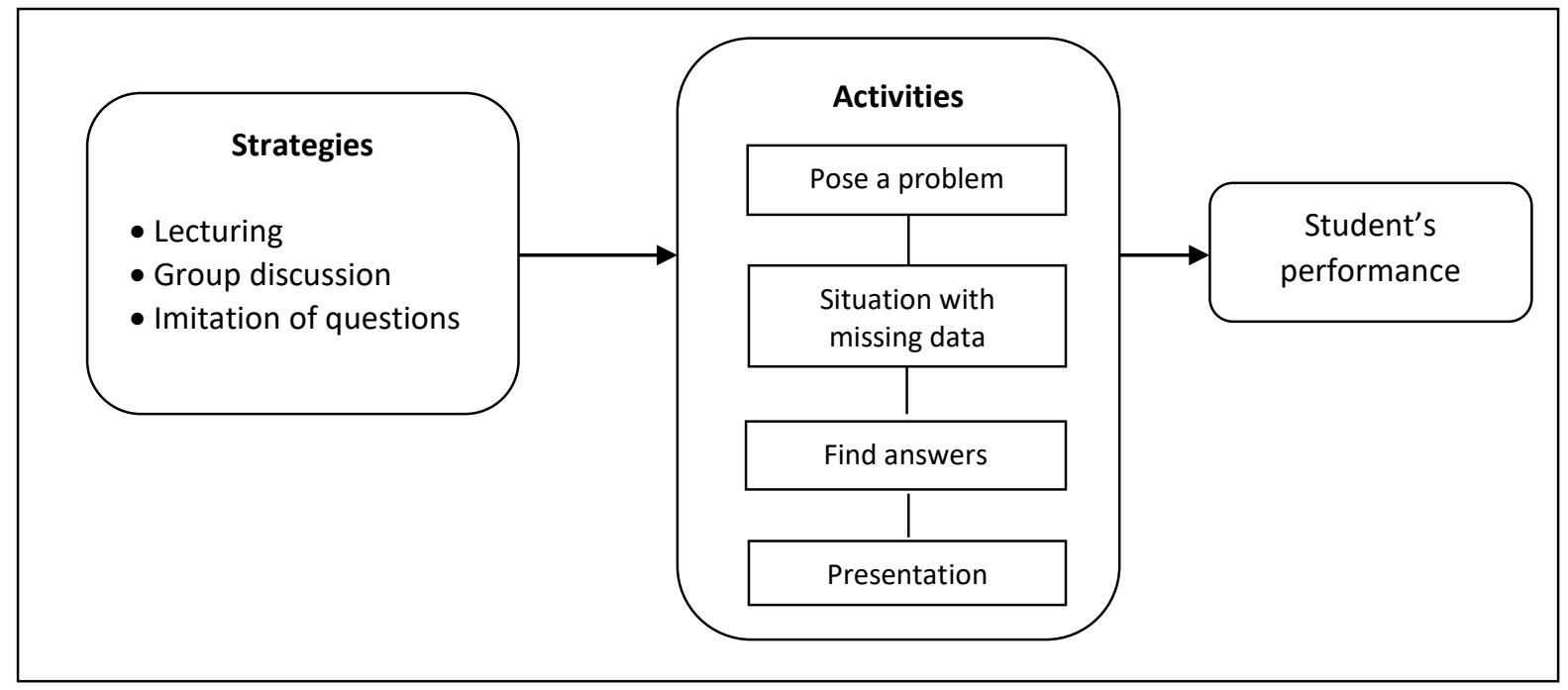

Fig. 6. Strategies and activities implemented in Problem-posing Multimedia Module

\section{Conclusion}

This paper focuses on identifying the suitable strategies and relevant activities to be implemented in Problem-posing Multimedia Module (PPMM). Using the systematic literature review, 14 papers 
INTERNATIONAL JOURNAL OF ACADEMIC RESEARCH IN BUSINESS AND SOCIAL SCIENCES Vol. 8, No. 12, Dec, 2018, E-ISSN: 2222-6990 @ 2018 HRMARS

relevant to the study's objectives were identified hence were closely analysed. All papers were found to have similar attributes and share the same themes that can be implemented in PPMM. These are critical thinking, communication, collaboration and creativity which are the primary conceptual elements advocated in the $21^{\text {st }}$-century learning. The strategies and activities however may be further analysed to strengthen the problem-posing instructional strategies for future research.

\section{Acknowledgment}

We would like to thank everyone that involved in this research. We also would like to thank our colleagues from Faculty of Educational Studies, Universiti Putra Malaysia of whom have provided insights and expertise that greatly assisted the research. We are grateful for their comments on the earlier version of the manuscript.

\section{References}

Beal, C. R., \& Cohen, P. R. (2012). Teach Ourselves: Technology to Support Problem Posing in the STEM Classroom. Creative Education, 03(04), 513-519. http://doi.org/10.4236/ce.2012.34078

Cankoy, O. (2014). Interlocked problem posing and children's problem posing performance in free structured situations. International Journal of Science and Mathematics Education, 12(1), 219238. http://doi.org/10.1007/s10763-013-9433-9

Chang, K. E., Wu, L. J., Weng, S. E., \& Sung, Y. T. (2012). Embedding game-based problem-solving phase into problem-posing system for mathematics learning. Computers and Education, 58(2), 775-786. http://doi.org/10.1016/j.compedu.2011.10.002

Christou, C., Mousoulides, N., Pittalis, M., Pitta-Pantazi, D., \& Sriraman, B. (2005). An empirical taxonomy of problem posing processes. ZDM - International Journal on Mathematics Education, 37(3), 149-158. http://doi.org/10.1007/s11858-005-0004-6

Çimer, A. (2012). What makes biology learning difficult and effective: Students' views. Educational Research and Reviews, 7(3), 61-71. http://doi.org/10.5897/ERR11.205

da Ponte, J. P., \& Henriques, A. (2013). Problem posing based on investigation activities by university students. Educational Studies in Mathematics, 83(1), 145-156. http://doi.org/10.1007/s10649-012-9443-5

Kapur, M. (2015). The preparatory effects of problem solving versus problem posing on learning from instruction. Learning and Instruction, 39, 23-31. http://doi.org/10.1016/j.learninstruc.2015.05.004

Kojima, K., Miwa, K., \& Matsui, T. (2013). Supporting mathematical problem posing with a system for learning generation processes through examples. International Journal of Artificial Intelligence in Education, 22(4), 161-190. http://doi.org/10.3233/JAI-130035

Kontorovich, I., Koichu, B., Leikin, R., \& Berman, A. (2012). An exploratory framework for handling the complexity of mathematical problem posing in small groups. Journal of Mathematical Behavior, 31(1), 149-161. http://doi.org/10.1016/j.jmathb.2011.11.002

Leung, S. kwan S. (2013). Teachers implementing mathematical problem posing in the classroom: Challenges and strategies. Educational Studies in Mathematics, 83(1), 103-116. http://doi.org/10.1007/s10649-012-9436-4

Mayer, R. E. (2010). Applying the science of learning to medical education. Medical Education, 
INTERNATIONAL JOURNAL OF ACADEMIC RESEARCH IN BUSINESS AND SOCIAL SCIENCES

Vol. 8, No. 12, Dec, 2018, E-ISSN: 2222-6990 @ 2018 HRMARS

44(6), 543-549. http://doi.org/10.1111/j.1365-2923.2010.03624.x

Mishra, S., \& lyer, S. (2015). An exploration of problem posing-based activities as an assessment tool and as an instructional strategy. Research and Practice in Technology Enhanced Learning, 10(1), 5. http://doi.org/10.1007/s41039-015-0006-0

N. Hasanah, Hayashi, Y., \& Hirashima, T. (2017). Investigation of learning environment for arithmetic word problems by problem posing as sentence integration in Indonesian language. Journal of Physics: Conference Series PAPER, 9(1), 3-10. http://doi.org/10.1088/17426596/755/1/011001

Nardone, C. F., \& Lee, R. G. (2010). Critical Inquiry Across the Disciplines: Strategies for StudentGenerated Problem Posing. College Teaching, 59(1), 13-22. http://doi.org/10.1080/87567555.2010.489077

Nerida F, E. (2015). Problem posing as an integral component of the mathematics curriculum: $A$ study with prospective and practicing middle-school teachers. In Mathematical Problem Posing: From Research to Effective Practice (pp. 513-543). http://doi.org/10.1007/978-1-46146258-3_25

Nunes, E. P. S., Luz, A. R., Lemos, E. M., \& Nunes, C. (2016). Approaches of participatory design the design process of a serious game to assist in the learning of hospitalized children. In Lecture Notes in Computer Science (including subseries Lecture Notes in Artificial Intelligence and Lecture Notes in Bioinformatics) (Vol. 9733, pp. 406-416). http://doi.org/10.1007/978-3-31939513-5_38

Rosli, R., Capraro, M. M., \& Capraro, R. M. (2014). The effects of problem posing on student mathematical learning: A meta-analysis. International Education Studies, 7(13), 227-241. http://doi.org/10.5539/ies.v7n13p227

Singer, F. M., \& Voica, C. (2013). A problem-solving conceptual framework and its implications in designing problem-posing tasks. Educational Studies in Mathematics, 83(1), 9-26. http://doi.org/10.1007/s10649-012-9422-x

Sousa, C. (2016). Problem-based learning on cell biology and ecophysiology using integrated laboratory and computational activities. Multidisciplinary Journal for Education, Social and Technological Sciences, 3(1), 118. http://doi.org/10.4995/muse.2016.3763

Sung, H.-Y., Hwang, G.-J., \& Chang, Y.-C. (2013). Development of a Mobile Learning System Based on a Collaborative Problem-Posing Strategy. Interactive Learning Environments, (April 2013), 116. http://doi.org/10.1080/10494820.2013.867889 